\section{Peach Pistil Growth Inhibition and Subsequent Bloom Delay by Midwinter Bud Whitewashing}

\author{
Edward F. Durner and Thomas J. Gianfagna \\ Rutgers Fruit Research Center, New Jersey Agricultural Experiment \\ Station, Cook College, Rutgers University, RD 2 Box 38, Cream Ridge, \\ NJ 08514
}

Additional index words. ethephon, fruit set, Prunus persica

\begin{abstract}
Fall-applied ethephon (100 ppm) delayed bloom by 6 days the following spring in peach [Prunis persica (L.) Batsch]. Whitewashing entire trees in January added 1 to 2 additional days of bloom delay to that provided by ethephon. Whitewashing delayed pistil elongation in quiescent buds from control trees, but did not significantly delay pistil elongation in buds from trees treated with ethephon. Pistils from ethephon-treated trees were significantly smaller than those from control trees from just before bud swell through bloom. Flower bud survival after freezes during bloom was enhanced for whitewashed compared to control buds as measured by fruit set. Chemical name used : 2-chloroethylphosphonic acid (ethephon).
\end{abstract}

The development of peach flower buds after rest proceeds with the accumulation of heat units (Werner et al., 1988). Peach bloom has been delayed by decreasing post-rest heat accumulation with overhead misting with water (Bauer et al., 1976); however, many detrireported (Howell and Dennis, 1981). Fall application of ethephon delays bloom in peach (Gianfagna et al., 1986) and increases latewinter hardiness of flower buds (Durner and Gianfagna, 1988). Whitten (1900) reported that the temperature of peach twigs could be as much as 9C above the air temperature on sunny winter days. Spraying peach trees with whitewash was recommended as a means of slowing down bud development in late winter, since the whitewash would reflect sunlight and thus reduce bud heat accumulation (Whitten, 1897), This study was initiated to determine: 1) if whole-tree whitewashing would reduce-pistil growth, and 2) if there would be any interactive effects of ethephon with whole-tree whitewashing on pistil growth and time of bloom in peach.

Ethephon (100 ppm) was applied to runoff on twelve 5-year-old peach trees ('Jerseydawn' on Lovell rootstock) on 17 Oct. 1988. Regulaid ( $0.1 \%$ by volume) (Kalo Manufacturing, Overland Park, Kan.) was added to assist spreading and was also used as a control on 12 trees. Six each of the ethephonand control-treated trees were sprayed on 18 Jan. 1989 with white interior flat latex wall paint (C and M Manufacturing, Minneapolis, Minn.) diluted with water (2 paint : 5 water). The experimental design was completely random. Flower buds were randomly

Received for publication 27 July 1989. New Jersey Agricultural Experiment Station, Publication no. D-12111-12-89, supported by state funds. The cost of publishing this paper was defrayed in part by the payment of page charges. Under postal regulations, this paper therefore must be hereby marked advertisement solely to indicate this fact. mental side effects of this method have been sampled on 3, 13, 24, and 31 Mar. 1989 from the periphery of trees from each of the four treatments. Pistil lengths of 10 flower buds per treatment were measured under a microscope. An analysis of variance (ANOVA) was performed on the data using a completely random factorial model. Data for each date were analyzed separately. Five twigs on each of three trees per treatment were tagged and the development of flower buds was monitored from late quiescence through full bloom. Observations were made on 27 and 29 Mar. and 2, 5, 10, 12, 14, 17, 19, 21, and 25 Apr. 1989. The percentages of total buds per twig in each of four developmental stages (quiescent, pink tip, balloon, and full bloom) on each observation date were calculated. An ANOVA was performed on the data using a split-plot model. Data were not transformed. Main plots were ethephon $\times$ whitewash treatments and subplots were observation dates. An ANOVA was also performed to determine if the total number of flower buds per centimeter of shoot length differed among treatments. On 15 May 1989 , the number of fruit set per centimeter of shoot length on 50 twigs per treatment was determined and an ANOVA performed on the data.

Neither ethephon (+ E) nor whitewashing $(+\mathrm{W})$ the trees significantly affected the mean number of flower buds per centimeter of shoot length $(0.4 \mathrm{buds} / \mathrm{cm})$. Main effects of ethephon and whitewashing were detected for the
3 Mar. sampling date. Ethephon significantly reduced pistil length compared to control buds, as expected (1.49 and $1.84 \mathrm{~mm}$, respectively), when measurements were made before appreciable accumulation of heat units (3 Mar.). Pistils from $+\mathrm{W}$ trees were also smaller than pistils from - W buds (1.62 vs. $1.71 \mathrm{~mm}$, respectively). On the 13,24 , and 31 Mar. sampling dates, a significant ethephon $\times$ whitewashing interaction was detected. As post-rest heat units accumulated for the later sampling dates, whitewashed buds had shorter pistils than nonwhitewashed buds only if not treated with ethephon the previous fall. Pistils from ethephon-treated buds were shorter than those from non-ethephontreated buds (Table 1). Ethephon treatment likely decreases the sensitivity of buds to heat unit accumulation by affecting flower bud dormancy (Gianfagna et al., 1988). Whitewashed buds accumulated heat units for growth at a slower rate, most likely as a result of reduced tissue temperature in bright sunlight (Whitten, 1900). We did not measure bud temperature in this experiment to confirm Whitten's (1900) observations.

During early bud development, from the quiescent stage, in which no visible growth was apparent, to the pink stage of development, a significantly greater proportion of $+\mathrm{W}$ buds remained in the quiescent stage when compared to $-\mathrm{W}$ buds (Fig. 1). Buds from $+E$ trees remained quiescent longer than buds from $-E$ trees. For four consecutive sampling dates beginning 5 Apr., buds from the $+\mathrm{W}+\mathrm{E}$ treatment developed more slowly than those given ethephon alone $(-\mathrm{W}+\mathrm{E})$

Retarded development was also evident for $+\mathrm{W}-\mathrm{E}$ buds in the pink stage on 2 Apr. While $74 \%$ of the buds were in the pink stage for - W - E trees, only $46 \%$ of the buds were at the pink stage on $+\mathrm{W}-\mathrm{E}$ trees. Delayed development of buds from the $+\mathrm{W}+\mathrm{E}$ trees was evident on 5 Apr. with $22 \%$ of the $+\mathrm{W}+\mathrm{E}$ buds in the pink stage compared to $42 \%$ of the $-\mathrm{W}+\mathrm{E}$ buds. On 10 Apr., $52 \%$ of the $+\mathrm{W}+\mathrm{E}$ buds were at pink, while $83 \%$ of the $-\mathrm{W}+\mathrm{E}$ buds were at this stage of development.

As bud growth progressed to the balloon stage, fewer $+\mathrm{W}-\mathrm{E}$ buds were at this stage compared to $-\mathrm{W}-\mathrm{E}$ buds on 12 Apr. (65\% and $80 \%$, respectively). On 21 Apr., a greater proportion of $+\mathrm{W}+\mathrm{E}$ buds was still in the balloon stage (44\%) compared to $14 \%$ for $-\mathrm{W}+\mathrm{E}$ buds. By this date, most of the $-\mathrm{W}+\mathrm{E}$ buds were at full bloom,

No significant differences were detected
Table 1. Pistil lengths of 'Jerseydawn' peach as affected by fall ethephon application and January whitewashing of flower buds.

\begin{tabular}{lcccc}
\hline \hline \multirow{2}{*}{$\begin{array}{l}\text { Observation } \\
\text { date }(\text { March })\end{array}$} & \multicolumn{2}{c}{- Ethephon } & \multicolumn{2}{c}{+ Ethephon } \\
\cline { 2 - 3 } & + Whitewash & - Whitewash & + Phitewash & - Whitewash \\
\hline & & $1.90 \mathrm{a}$ & $1.46 \mathrm{a}$ & $1.54 \mathrm{a}$ \\
24 & $1.63 \mathrm{~b}$ & $2.94 \mathrm{a}$ & $2.31 \mathrm{a}$ & $2.23 \mathrm{a}$ \\
31 & $2.70 \mathrm{~b}$ & $6.71 \mathrm{a}$ & $4.14 \mathrm{a}$ & $4.00 \mathrm{a}$ \\
\hline
\end{tabular}

${ }^{2}$ Mean separation within ethephon treatment and date by Fisher's protected LSD. Data are means of 10 observations. 


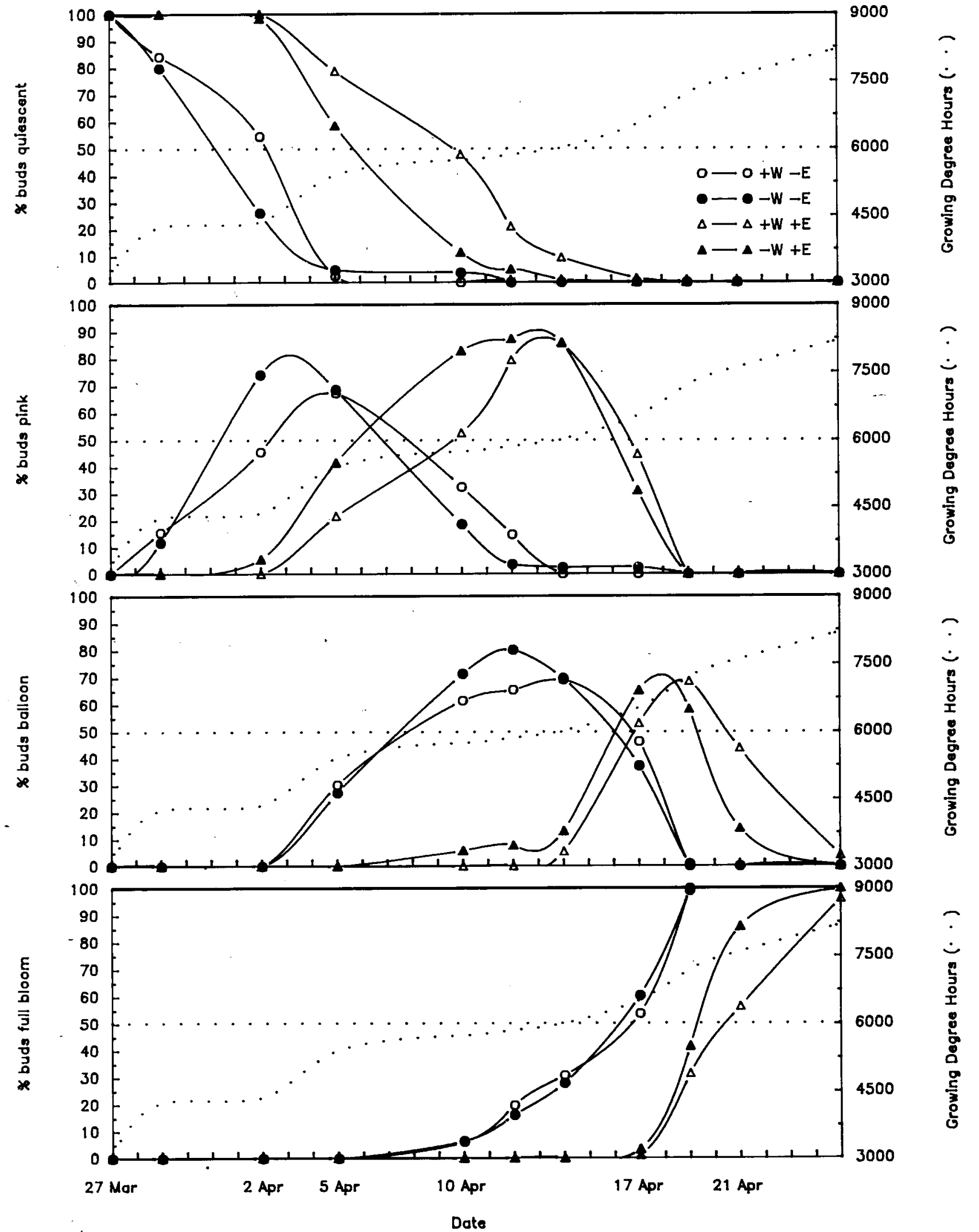

Fig.1. Development of 'Jerseydawn' peach flower buds over time as affected by October ethephon treatment and January whitewashing of entire trees.

on any date for the proportion of buds at the full bloom stage on the $+\mathrm{W}-\mathrm{E}$ and $-\mathrm{W}-\mathrm{E}$ trees. However, significantly fewer $+\mathrm{W}+\mathrm{E}$ buds compared to $-\mathrm{W}+\mathrm{E}$ buds were at full bloom on 19 and 21 Apr. (Fig. 1). Since blossoms at the full bloom stage of development are most susceptible to freeze injury
(Proebsting and Mills, 1961), implications for the practical significance of delayed bud development can be drawn from the data in Fig. 1. If one considers when $100 \%$ full bloom was reached, then ethephon delayed bloom by nearly 6 days. This delay reflects a reduced rate of flower development with fall ethephon treatment. This reduced development is especially evident if one considers the period between 5 and 18 Apr. On 17 Apr., $50 \%$ of the buds not treated with ethephon were at full bloom, while $<5 \%$ of the ethephon-treated buds were at full bloom. A sharp increase in the proportion of ethephon- 
treated buds at full bloom occurred during the 2 days from 17 to 19 Apr., which was concomitant with a rapid accumulation of heat units. This rapid accumulation was due to daily highs of 24 and $26 \mathrm{C}$ on 18 and 19 Apr., respectively. Ethephon-treated flower buds appear to need more heat units to reach a specific stage of development, rather than simply a higher base temperature for development, since the temperatures reached $24 \mathrm{C}$ on 5 and 6 Apr., yet ethephon bud development remained delayed. Apparently, the assumed temperature elevation in $-\mathrm{W}+\mathrm{E}$ buds was still below the threshold required for ethephon-treated pistils to grow and/or the number of heat units required for visible growth had not yet accumulated in ethephontreated buds. Once the air temperatures increased, the whitewash effect was no longer detected in the $+\mathrm{W}-\mathrm{E}$ trees, but was in the ethephon-treated trees. Perhaps combining higher air temperatures with elevated tissue temperatures increased the heat unit accumulation in $-\mathrm{W}-\mathrm{E}$ buds. With $-\mathrm{W}-\mathrm{E}$ trees, the heat units provided by higher air temperatures later in bloom were sufficient, such that elevated tissue temperatures likely in - W - E buds were not needed to supply the heat units needed for growth.

In 1989, the 1- to 2-day bloom delay provided by whitewashing was protective. Severe low temperatures were recorded in tree canopies on 12 Apr. (- 5.0C), 18 Apr. (-4.4C), 20Apr. (-1.7C), 23Apr. (-3.9C), and 24 Apr. (- 5.0C). Fruit set, a relative indication of bud survival, was significantly enhanced by whitewashing $(0.05$ and 0.09 fruit/cm for $-\mathrm{W}-\mathrm{E}$ and $+\mathrm{W}-\mathrm{E}$ buds, respectively) but not for ethephon-treated trees (0.07 fruit/cm for both - W + E and $+\mathrm{W}+\mathrm{E})$. Intrinsic hardiness was enhanced in ethephon-treated pistils (Durner and Gianfagna, 1988), and thus the slight protection provided by whitewashing for control buds was not evident or additive for ethephontreated buds. In addition, smaller pistils have been suggested as being hardier than similar but larger pistils (Howell and Dennis, 1981); thus, the smaller pistils of whitewashed buds may have been somewhat hardier than the larger pistils of nonwhitewashed buds.

\section{Literature Cited}

Bauer, M., C.E. Chaplin, G.W. Schneider, B.J. Barfield, and G.M, White. 1976. Effects of evaporative cooling during dormancy on 'Redhaven' peach wood and fruit bud hardiness. J. Amer. Soc. Hort. Sci. 101:452-454.

Durner, E.F. and T.J. Gianfagna. 1988. Fall ethephon application increases peach flower bud resistance to low-temperature stress. J. Amer. Soc. Hort. Sci. 113:404-406.

Gianfagna, T. J., R.P. Marini, and S. Rachmiel. 1986. Effect of ethephon and $\mathrm{GA}_{3}$ on time of flowering in peach. HortScience 21:69-70.

Gianfagna, T.J., E.F. Durner, and G.S. Teiger. 1989. Reducing low temperature injury to peach flower buds with ethephon. Acts. Hort. 239:203206.

Howell, G. S., Jr. and F.G. Dennis, Jr. 1981. Cultural management of perennial plants to maximize resistance to cold stress, p. 175-204. In:
C.R. Olein and M.N. Smith (eds.). Analysis and improvement of plant cold hardiness. CRC Press, Boca Raton, Fla.

Proebsting, E.L. and H.H. Mills. 1961. Loss of hardiness by peach fruit buds as related to their morphological development during the pre-bloom and bloom period. Proc. Amer. Soc. Hort. Sci. 78:104-110.

Werner, D. J., B.D. Mowrey, and E. Young. 1988.
Chilling requirement and post-rest heat accumulation as related to difference in time of bloom between peach and western sand cherry. J. Amer, Soc. Hort. Sci. 113:775-778.

Whitten, J.C. 1897. Winter protection of the peach. Mo. Agr. Expt. Sta. Bul., 38.

Whitten, J.C. 1900. The relation of color to the growth of fruit buds of-the peach on sunny days in winter. Proc. Amer. Pom. Soc. 44-50. 